\title{
SECRECY IN THE MITHRAS CULT: CONCEALMENT, COGNITION AND SOCIAL COHESION
}

\begin{abstract}
Summary: Secrecy was one of the major features of the so-called mystery cults that met with significant diffusion and popularity throughout the Greco-Roman world. The Roman cult of Mithras was a particular example of mysteries that took place in secret, without any public aspect.

This paper examines the ways in which the major symbolic systems of the Mithras cult, the mithraea, the scene of the tauroctony and the hierarchy of the initiatory grades, would have operated as elaborated security systems that would have contributed to the secrecy of the cult, obstructing both the physical and cognitive access of the uninitiated to their symbolic meanings.

Further, the cognitive processes that mediate the attractiveness of secret communities and forge social cohesion among members of secret groups are explored. It is argued that secrecy was a crucial aspect which would have promoted the formation of close exclusive communities of Mithraists and the development of social cohesion between the cult members.
\end{abstract}

Key words: Mithras, Mithraism, secrecy, concealment, social cohesion, cognition, emotional arousal, modes of religiosity

\section{INTRODUCTION}

The Mithras cult was one of the so-called 'mystery' or foreign cults ${ }^{1}$ that developed and enjoyed increased popularity throughout the Greco-Roman world. Although these religious traditions displayed varied aspects and multiple characteristics that have raised debates among scholars regarding their aggregation under a common term and definition, they shared some elementary features that differentiated them from other

\footnotetext{
${ }^{1}$ On the various terms suggested by scholars in order to determine the religious traditions that involved initiation see e.g. CUMONT, F.: Les religions orientales dans le paganisme romain. Paris 19061929 (reedited by BONNET and VAN HAEPEREN. Torino 2006); ASCOUGH, R.: What are They Saying about the Formation of Pauline Churches? New York 1998, $101 \mathrm{n} .1$; BowDEN, H.: Mystery Cults of the Ancient World. Princeton 2010; BREMMER, I.: Initiation into the Mysteries of the Ancient World. BerlinBoston 2014, xi-xiii.
} 
religious systems of Greco-Roman antiquity and enabled their classification into the same sort of religious practices. These features mainly clustered around the notion of secrecy and the emotional arousal induced during initiatory rituals. ${ }^{2}$

Initiation was the major component of the mystery cults that consisted in the voluntary participation of the initiates in ritual practices, which took place in secrecy, and entailed their integration in the community of adherents. ${ }^{3}$ Along with this secret aspect, the vast majority of these religious traditions involved additional public practices and performances that uninitiated could attend, or even participate in them. The Mithras cult comprised a unique case: it was identified with its mysteries - that is, with initiatory rituals performed in secrecy ${ }^{4}$ - lacking any public aspect accessible to outsiders. ${ }^{5}$

This paper investigates how the operation of the Mithras cult in secrecy was facilitated and supported by its structural components and the latter's symbolic connotations that were unveiled in the mystery context. In particular, it is argued that the cult meeting places - the caves as they were called by their contemporaries, or the mithraea as they have been called by modern researchers - the scene of the tauroctony ${ }^{6}$ and the hierarchy of the initiatory grades anchored the actualization of the cult mysteries and simultaneously ensured the incomprehensibility of the mysteries for the uninitiated and potential intruders.

The paper further examines how the experience of initiation and the sharing of this secret experience contributed to social cohesion and the development of close Mithraic communities. Employing Harvey Whitehouse's and Jonathan A. Lanman's theory of the modes of religiosity ${ }^{7}$ and their correlations with different types of social cohesion, I suggest that the initiatory rituals of high emotional arousal along with the sharing of a secret world view by the participants forged close relationships of fictive kinship that increased the group's social cohesion and solidarity.

\section{SECRECY AND COMMUNICATION - WHAT WAS THE SECRET IN THE MITHRAS CULT?}

Every piece of information about any kind of knowledge, action or experience can be a secret, when it is followed by an intentional control over its transmission and com-

\footnotetext{
${ }^{2}$ On the difficulties of definition and the common features of the mystery cults see e.g. BURKERT, W.: Ancient Mystery Cults. Cambridge, MA. - London 1987, 7-11; SMITH, J. Z.: Drudgery Divine. On the Comparison of Early Christianities and the Religions of Late Antiquity. Chicago 1990, 107-108; ASCOUGH (n. 1) 52-54; GORDON, R. L.: Mysteries. In HORNBlOWER, S. - SPAWFORTH, A. - EIDINOw, E. (eds): The Oxford Classical Dictionary (4th edition). Oxford 2012, 990; BREMMER (n. 1) xii.

${ }^{3}$ See e.g. BURKERT (n. 2) 7-8, 10; BREMMER (n. 1) viii.

${ }^{4}$ On the etymological association of the term mystery (mystērion) with initiation and secrecy see e.g. BURKERT (n. 2) 8-9; SMITH (n. 2) 56-57; BREMMER (n. 1) vii-viii.

${ }^{5}$ See BURKERT (n. 2) 42; BECK, R. L.: The Religion of the Mithras Cult in the Roman Empire. Mysteries of the Unconquered Sun. Oxford 2006, 2-3.

${ }^{6}$ The term 'tauroctony' is also a neologism which is used to describe the omnipresent in the mithraeas' visual representation of Mithras, who slaughters a bull.

${ }^{7}$ Whitehouse, H. - Lanman, J. A.: The Ties That Bind Us: Ritual, Fusion, and Identification. Curr. Anthropol. 55.6 (2014) 674-695.
} 
munication. ${ }^{8}$ Despite Georg Simmel's ${ }^{9}$ remark that "A secret that two know is no longer a secret", secret information acquires social value when it is shared by a group of people ${ }^{10}$ who know something that others are not allowed to know. However, the sharing of a specific set of information among the insiders and the exclusion of outsiders from this knowledge implies what Beryl L. Bellman ${ }^{11}$ has called the "paradox of secrecy": the revelation of secret information is accompanied by a "do-not-talkabout-it" prohibition along with instructions about how this information should be concealed. This paradox is resolved when the context of revelation as well as the social strategies and material means of concealment are taken into account. In this view, the social significance of secrecy does not depend so much on the contents of the secret and the consequences of its exposure as on the means of management and the conditions and rules of communication of the secret information. ${ }^{12}$

In the Greco-Roman mystery cults, secrecy did not consist so much in the revelation of a secret body of creeds and precepts that was orally transmitted and taught to the initiates during the initiatory rituals. What was mainly forbidden to talk about (aporrhēton and arrhēton) was the experience of initiation ${ }^{13}$ that was normally accompanied by high emotional arousal. ${ }^{14}$ Initiation was a matter of personal choice. Although the motives for this choice were not the same for all participants and for all the mystery cults, there was usually the promise of establishment of a personal relationship to the worshipped deity and the revelation of an alternative schema for interpreting the world that was intended only for the god's adherents. ${ }^{15}$

The Mithras cult, in particular, developed a specific cosmology and world view that was revealed to the initiates who, along with the common experience of initiation and the personal relationship with Mithras, shared a common view of the universe and inhabited new roles and positions within the cosmos. At the heart of the cult was the mystery of the souls' journey during which the initiates' souls would ascend throughout the heavens to the sphere of the fixed stars where they would reach apogenesis - release from genesis on earth and mortality. ${ }^{16}$ This celestial travel would have been a gradual process that involved initiation into the hierarchical cult grades,

${ }^{8}$ See Bellman, B. L.: The Paradox of Secrecy. Human Studies 4 (1981) 1-2.

${ }^{9}$ SIMMEL, G.: The Sociology of Secrecy and of Secret Societies. AJS 11.4 (1906) 471.

${ }^{10} \mathrm{~A}$ group of people is determined by at least two persons.

${ }^{11}$ BELLMAN (n. 8) 10, 21

${ }^{12}$ Bellman (n. 8) 21; Urban, H. B.: The Torment of Secrecy: Ethical and Epistemological Problems in the Study of Esoteric Traditions. HR 37.3 (1998) 210, 212.

${ }_{14}^{13}$ See BURKERT (n. 2) 9.

${ }^{14}$ According to BURKERT (n. 2) 102 initiatory rituals usually involve physical pain, distress, humiliation or even injuries to participants.

${ }^{15}$ See e.g. BuRKERT (n. 2) 8; R. L. GoRDOn: Authority, Salvation and Mystery in the Mysteries of Mithras. In HuSKInSON, J. - BEARD, M. - REYNOLDS, J. (eds): Image and Mystery in the Roman World: Three Papers Given in Memory of Jocelyn Toynbee. Gloucester 1988, 45; BREMMER (n. 1) xi.

${ }^{16}$ On the notions of genesis and apogenesis in the Mithras cult see e.g. Porphyry, On the Cave, 22. 14- 24; GORDON, R. L.: Reality, Evocation and Boundary in the Mysteries of Mithras. JMS 3 (1980) 38-39; BeCK, R. L.: Planetary Cods and Planetary Orders In The Mysteries of Mithras. Leiden 1988, 28-30, 73-85, 93-100; BECK, R. L.: Ritual, Myth, Doctrine, and Initiation in the Mysteries of Mithras: New Evidence From A Cult Vessel. JRS 90 (2000) 145-180; BECK: The Religion (n. 5) 84. 
on the one hand, and ascension through the sequential planetary spheres, on the other hand, as they were defined by the Ptolemaic cosmological model. ${ }^{17}$

Beyond such broad description, based on scanty literary testimonies, ${ }^{18}$ we have no more ancient written records of what happened during the Mithraic mysteries. And this is reasonable if we take into account the fact that Mithraists were not allowed to discuss with non-initiates their initiatory experiences, their positions and roles in the cult community and the view of the universe as it was revealed in the mystery context. What, however, we can infer from the abundant archaeological remains is that the main cult structures - the mithraea, the scene of the tauroctony and the grade hierarchy - would have been used as effective means for ensuring the concealment of the view of the cosmos from the outsiders, as it was experienced by the initiates, as well as for classifying access into this world view for the cult members.

\section{MEETING IN THE CAVE, MEETING IN SECRET}

The reservation of secrecy and thereby the very existence of secret communities involve complex social strategies that ensure that the secret-keepers have their lips sealed. However, along with the attitudes, expectations, emotions, and beliefs that are induced in participants during social intra-group interaction in order to reserve their commitment to the secret and the community, several artificial means are employed that support concealment and inhibit the access of curious intruders to the concealed information. ${ }^{19}$

In the Mithras cult, both the location and the design of the mithraea contributed to the secrecy of the mysteries that were performed within the cult space. Mithraists called their meeting places 'caves ${ }^{, 20}$ and this appellation implies a major feature of the constructions. Similarly to natural caves, the mithraea were established in places that were not identifiable from the outside. As Roger Beck ${ }^{21}$ has aptly pointed out, the Mithraic caves had "an inside without an outside". In fact, the Mithraists preferred caves and rock caverns in order to establish their cult places. Even when such natural settings were not available, especially in the cities and urban centers, they chose rooms and halls inside bigger buildings - interiors that were not traceable from the outside. Therefore, non-initiates who walked around in the cities could not locate a mithraeum by exterior spatial signs and markers. Participants should a priori know where the cult meetings took place. New candidates should be informed about where they should go in order to be initiated into the mysteries. ${ }^{22}$

${ }^{17}$ See Ptolemy, Almagest; Tetrabiblos; for a brief description of the Ptolemaic model see MARTIN, H. L.: Hellenistic Religions: An Introduction. Oxford 1987, 7-8.

${ }^{18}$ Mainly on Porphyry's On the Cave 6, which was based on information derived from Eubulus, Numenius and Cronius, and a few references in De Abstinentia.

${ }^{19}$ RIGNEY, D.: Secrecy and Social Cohesion. Society 16.4 (1979) 52.

${ }^{20}$ See Porphyry's account (On the Cave 6) that is confirmed by the archaeological findings.

${ }^{21}$ BECK: The Religion (n. 5) 106.

${ }^{22}$ Although many mithraea stood in the very center of cities, where it was impossible that many people would not know that these were the meeting places for Mithraists, they still lacked external markers 
But even when someone gained physical access to a mithraeum, the symbolic connotations of its design and decoration remained hidden. Symbolic investments operated as a further means of inhibiting cognitive access to the internal meanings of the cult. Upon entering a Mithraic cave, a person would be in an oblong hall with a vaulted ceiling, cut off from its external surroundings. There were no windows or other openings in the walls that would allow people to see out or to orient themselves in the internal space in reference to cardinal points. Thus, at this level of space-perception, the mithraeum remained an isolated place on earth.

During participation in the rituals, the terrestrial space of a mithraeum could have been gradually and imaginatively perceived as a replica of the celestial realm ${ }^{23}$ where the mystery of the souls' journey could be actualized. People who lived, acted and interacted in the Greco-Roman world would have shared some popular mental representations and ideas about the universe influenced by the Ptolemaic cosmological model. ${ }^{24}$ Although celestial symbolism is explicitly evident only in a few mithraea, ${ }^{25}$ during initiation into the Mithraic mysteries, the initiates would be stimulated to recognize correspondences between the various material components of the ritual space and their own internalized images of the universe. Then, employing Fauconnier's and Turner's Blending Metaphor Theory, ${ }^{26}$ we can assume that through the cognitive processes of composition, completion, elaboration, and compression of these correspondences, the Mithraists could metaphorically perceive the mithraeum as the universe. Running the blend, however, was not an automatic cognitive process. The generation of the blended mental space of the Mithraic universal microcosm demanded

of the locations. However, despite the fact that the Mithraic caves were hidden from public view, their establishments were not prohibited by the official authorities. The emplacements were often made available for the congregations thanks to a decree of the local Senate or to an Imperial grant, for they were often - as F. COARELli (Topografia Mitriaca di Roma. In BIANCHI, U. [ed]: Mysteria Mithrae. Leiden 1979, 69-79) underlined - public or quasi-public spaces (e.g. the Mithraea of Aquincum,which were located close to the city Forum; the Mithraeum of the Circus Maximus at Rome, and that of the military quarter of Dura). Moreover, the expensive sculptures and paintings were often dedicated to the Emperor or the Imperial family, and the aim of the Patres who payed fines for this was that of letting the Emperor and the Imperial administration know that they had payed a lot on their behalf.

${ }^{23}$ According to Porphyry (On the Cave 6), the Mithraic caves replicated the image of the cosmos (eikona kosmou) as it was instantiated by Zoroaster who dedicated the first cave to Mithras.

${ }^{24}$ See Cumont, F.: Astrology and Religion among the Greeks and Romans. Trans. J. B. Baker. New York 1960 (1912) 32, 51-52; BARTON, T.: Ancient Astrology. London 1994; BECK, R. L.: A Brief History of Ancient Astrology. Oxford 2007; MARTIN, L. H.: The Landscapes and Mindscape of the Roman Cult of Mithras. In MARTIN, L. H.: The Minds of Mithraists: Historical and Cognitive Studies in the Roman Cult of Mithras. London - New Delhi - New York - Sydney 2015, 82.

${ }^{25}$ The most typical example is the Mithraeum of Sette Sfere in Ostia; see CuMONT, F.: Textes et monuments figurés relatifs aux mystères de Mithra. Vol. II. Bruxelles 1896, 243-245; BECATTI, G.: Scavi di Ostia. II: I Mitrei. Roma 1954, 47-51; GoRDON, R. L.: The Sacred Geography of a Mithraeum: The Example of Sette Sfere. JMS 1.2 (1976) 146-147; BECK, R. L.: Cosmic Models: Some Uses of Hellenistic Science in Roman Religion. In BARNES, T. D. (ed.): The Sciences in Greco-Roman Society. APEIRON 27 (4). Edmonton 1994, 100, 106; BECK: The Religion (n. 5) 103-115.

${ }^{26}$ FAUCONNIER, G. - TURNER M.: Conceptual Integration Networks. Cognitive Science 22.2 (1998) 133-187; FAuconnier, G. -Turner, M.: The Way We Think: Conceptual Blending and the Mind's Hidden Complexities. New York 2002. FAUCONNIER, G. - TURnER, M.: Conceptual Blending, Form, and Meaning. In FASTREZ, P. (ed.): Recherches en Communication, 19: Sémiotique Cognitive (2003) 57-86. 
initiation into the mysteries, participation in the rituals and familiarization with the internal meanings of the cult, in order for the initiates to start 'seeing' in the mithraea an image of the cosmos to be unveiled.

\section{CODING AND DECODING THE SCENE OF THE TAUROCTONY}

The scene of the tauroctony was a ubiquitous element of the mithraea. Contrary to the diversity of other visual representations that occasionally decorated the Mithraic caves ${ }^{27}$ and despite some secondary variations in the scene, the tauroctony displays a unique uniformity of composition. In particular, it represents Mithras slaughtering a bull with a dagger, while some other human-like figures and animals are present and attend the scene. This primary description derives from the recognition of the icons that compose the visual representation. However, the ancient written testimonies remain silent regarding the meanings of the scene within the cult context.

Modern scholars have suggested various interpretations. The narrative organization of human thought, ${ }^{28}$ that tends to generate stories from visual representations, grounds the interpretations that intend to reconstruct a mythical narrative from the scene. ${ }^{29}$ Such interpretations have been further enriched by the association of the cult with its alleged Persian origins and its integration into the Greco-Roman historical context. ${ }^{30}$ Furthermore, many scholars have interpreted the tauroctony in reference to its position within the universal microcosm of the mithraeum. Such interpretations trace multiple astrological symbolisms in the visual signs of the scene and the associations between these signs. ${ }^{31}$ Thus, the icons that composed the scene have been inter-

${ }^{27}$ See e.g. a series of frescoes found in the mithraeum of Capua Vetere (CLAUSS, M.: The Roman Cult of Mithras: The God and His Mysteries. Trans. R. L. Gordon. New York 2000, 103; MARTIN, H. L.: Performativity, Narrativity and Cognition: Demythologizing The Roman Cult of Mithras. In BRAUN, W. (ed.): Rhetoric and Reality in Early Christianity. Waterloo 2004, 191-193) or the reliefs from Nesce in Lazio and Virunum (GORDON: Authority [n. 15] 67).

${ }^{28}$ See e.g. SJÖBLOM, T.: Storytelling: Narratives of the Mind and Modes of Religiosity. Historical Reflections/Reflexions Historiques 31.2 (2005) 235-254; WHITEHOUSE, H.: Cognitive Historiography: When Science Meets Arts. Historical Reflections/Reflexions Historiques 31.2 (2005) 312-315; MARTIN, L. H.: The Promise of Cognitive Science for the Historical Study of Religions, with Reference to the Study of Early Christianity. In LUOMANEN, P. - PYYSIÄINEN, I. - URO R. (eds): Explaining Early Judaism and Christianity: Contributions from Cognitive and Social Sciences. Leiden 2007, 39-40; GeErtz, W. A: Too Much Mind and Not Enough Brain, Body and Culture: On What More Needs to be Done in the Cognitive Study of Religion. Historia Religionum 2 (2010) 29-30.

${ }^{29}$ See e.g. CUMONT, F.: Textes et monuments figures relatifs aux mysteres de Mithra [MMM]. Vol. I. Bruxelles 1899, 179-213; CLAUSS (n. 27) 62-101; DIRVEN, L.: The Mithraeum as Tableau Vivant: A Preliminary Study of Ritual Performance and Emotional Involvement in Ancient Mystery Cults. RRE 1.1 (2015) 20-50.

${ }^{30}$ See e.g. Cumont: Astrology (n. 24) CUMONT: MMM (n. 28); TURCAN, R.: The Cults of the Roman Empire. Trans. A. Nevill. Malden MA - Oxford 1996, 195-196, 199-200; TURCAN, R.: Mithra et le mithriacisme. Paris 2000; BECK: The Religion (n. 5) 26-30.

${ }^{31}$ Stark was the first who suggested the astrological symbolism of the tauroctony; see STARK, K. B.: Die Mithrasstein von Dormagen. Jahrbücher des Vereins von Altertumsfreunden im Rheinlande 46 (1869) 1-25. For a very brief representation of the astrological approaches to tauroctony see BECK: Planetary Cods (n. 16) 236; BECK: The Religion (n. 5) 36-38. 
preted as representing various celestial elements and bodies or astral constellations. ${ }^{32}$ The whole composition of the tauroctony has been interpreted as representing various sections of the heavens, as they were seen from the earth in particular periods of the year, ${ }^{33}$ or as a kind of celestial calendar, ${ }^{34}$ clock $^{35}$ or astral chart. ${ }^{36}$

All modern interpretations of the tauroctony have received critiques regarding their plausibility in reference to the available ancient sources or the major historical assumptions about the Mithraic cult. There are scholars, on the one hand, who argue that the existence of a myth is not testified to by any evidence and would have not been a precondition for the existence of the cult. ${ }^{37}$ The astrological interpretations, on the other hand, have been characterized as too tentative and elaborate constructions, the comprehension of which would demand complex astrological knowledge that ordinary people of the Greco-Roman world would have not necessarily had. ${ }^{38}$

If, however, we assume that the scene communicated meanings to the perceivers and we shift the interest from what these meanings were to the ways in which these meanings were transmitted, we can gain some insights into the role of the tauroctony in the ritual context. The iconic composition of the representation would have been easily comprehensible to anyone who looked at the scene in terms of the ordinary experience and perception of the world shared by people. ${ }^{39}$ The identification of the image of Mithras presupposed that the viewers at least knew that this scene was an artifact of the Mithraic cult. The perception of further meanings and connotations in the visual representation, however, demanded conceptual resources that would have been acquired during participation in the mysteries. There is no evidence for the existence of a specific body of creeds and precepts that would have been orally taught and transmitted by some cult authority - a priesthood or a sacred leadership - and would

${ }^{32}$ See e.g. RUTGERS, A. J.: Rational Interpretation of the Ritual of Mithras, and of Various Other Cults. In LeEMANS, E. A. (ed.): Anamnesis: Gedenkboek prof. dr. E.A. Leemans. Brugge 1970, 305-315; BAUSANI, A.: Notte sulla preistoria astronomica del mito di Mithra. In BIANCHI, U. (ed.): Mysteria Mithrae. Leiden 1979, 503-513; SPEIDEL, M.: Mithras-Orion: Greek Hero and Roman Army-God [ÉPRO 81]. Leiden 1980; SANDELIN, K. G.: Mithras-Auriga? Arctos 22 (1988) 133-135; UlanSEY, D.: The Origins of the Mithraic Mysteries: Cosmology and Salvation in the Ancient World. New York - Oxford 1989; BECK, R. L.: In the Place of the Lion: Mithras in the Tauroctony. In HinNELLS, J. R. (ed): Studies in Mithraism. Rome 1994, 29-50; WeISS, M.: Mithras, der Nachthimmel: Eine Dekodierung der römischen Mithraskultbilder mit Hilfe des Avesta. Traditio 53 (1998) 1-36; JACOBS, B.: Der Herkunft und Entstehung der römischen Mithrasmysterien: Überlegungen zur Rolle des Stifters und zu den astronomischen Hintergründen der Kultlegende. Konstanz 1999.

${ }^{33}$ See e.g. BECK: The Religion (n. 5) 190-227; JACOBS (n. 31).

${ }^{34}$ See e.g. InSLER, S.: A New Interpretation of the Bull-Slaying Motif. In DE BOER, M. B. EDRIDGE, T. A. (eds): Hommages à Maarten J. Vermaseren [ÉPRO 68]. Leiden 1978, 519-538. $115-148$

${ }^{35}$ See e.g. NORTH, J. D.: Astronomical Symbolism in the Mithraic Religion. Centaurus 33 (1990)

${ }^{36}$ See e.g. BECK: The Religion (n. 5) 193-194, 203.

${ }^{37}$ See e.g. MARTIN, H. L.: Reflections on the Mithraic Tauroctony as Cult Scene. In HiNNELLS, J. R. (ed.): Studies in Mithraism. Rome 1994, 217-224; MARTIN: Performativity (n. 27) 187-217; BECK: The Religion (n. 5) 16-25.

${ }^{38}$ See e.g. BREMMER (n. 1) 130.

${ }^{39}$ On the gradual interpretation of the tauroctony as an iconic, indexical and symbolic representation in C. S. Peirce's terms see Panagiotidou, O.: The Cognitive Route of 'Star Talk': The Scene of Tauroctony as a System of Signs. Pantheon 7.1 (2012) 70-78. 
have provided direct interpretations of the tauroctony. That implies the possibility that the participants could gradually extract the symbolic meanings of the scene during the lived experience of initiation. During this process, the initiates could peel off multi-layered symbolic meanings and metaphorical connotations of the scene. Such interpretations would not necessarily be mutually exclusive. Simultaneously, the very fact that the symbolic meanings of the scene would have been not directly perceivable and comprehensible by "naïve viewers ${ }^{40}$ who had not participated in the Mithras cult, would have operated as an effective security system that would block the cognitive access of these viewers to the internal meanings of the cult.

Although the interpretations of the tauroctony as a symbolic composition may seem infinite in terms of personal experiences and reflections of individual participants and local cult communities, the ubiquity and uniformity of the tauroctony implies that there should have been a fixed hidden message in the scene that would have played a significant role in the cult. Although we cannot confidently extract such hidden message, we can assume that the scene could have been a kind of secret code ${ }^{41}$ that could ensure the covert transmission of the major precepts of Mithraism, as the cult spread and new cult communities were established throughout the Greco-Roman world.

\section{THE GRADE HIERARCHY AND THE CLASSIFICATION OF INFORMATION}

Along with the material means used by secret communities against potential external intruders, further measures were taken that controlled the distribution of information among the group-members. Since the maintenance of secrecy greatly depends on the loyalty of the individual members, internal hierarchies and gradation of access to secret knowledge would develop as internal means for forging commitment to the group and for minimizing the risk of exposure. ${ }^{42}$

In the Mithraic mysteries, the hierarchy of the seven initiatory grades comprised an internal structure that determined the identities and roles inhabited by the initiates during participation in the cult. ${ }^{43}$ Although there is no adequate evidence that the grade hierarchy was omnipresent and strictly employed in all Mithraic communities, where it was present, it could further operate as a means of controlling the access of

\footnotetext{
${ }^{40}$ With the term naïve viewers we refer to anyone who would look at the scene of the tauroctony out of the ritual context. Although there is no evidence that in the Greco-Roman era non-initiates ever got into the mithraea and had the opportunity to see a tauroctony, we cannot exclude the possibility that at least some of the designers and constructors of these artifacts (e.g. sculptors or painters) would have not been members of the cult communities. And we cannot either rule out the possibility of accidental encounters with the scene during the transmission of the cult. Modern viewers can also be added to naïve viewers, since they are not members of the ancient Mithraic communities.

${ }^{41}$ On secret codes and other artificial means for ensuring secrecy see RIGNEY (n. 19) 53.

42 RigNeY (n. 19) 52.

${ }^{43}$ The names of the seven initiatory grades were preserved by Jerome in one of his letters (to Laeta, CVII): Raven (Corax), Nymphus, Soldier (Miles), Lion (Leo), Persian (Perses), Sun-Runner (Heliodromus), and Father (Pater).
} 
the participants to the Mithraic world view. As they were being initiated into each grade, the initiates would acquire only the information and knowledge required for accomplishing their ritual roles and cult duties. ${ }^{44}$ Simultaneously, initiation into the sequential grades would have been accompanied by high emotional arousal and demonstrations of personal commitment to the cult-community that justified the expansion of the initiate's access to the secret knowledge and world view. ${ }^{45}$ As far as the participants proceeded in the grade hierarchy, they would have acquired more conceptual means and knowledge that would enable them to perceive the universal macrocosm imprinted in the Mithraic cave, in order to penetrate into the deeper symbolic layers of the tauroctony and to reach a more complete view of the universe.

\section{EMOTIONAL AROUSAL, COGNITION, SECRECY AND SOCIAL COHESION}

Much ink has been spilled on the relationship between rituals and social cohesion. ${ }^{46}$ Harvey Whitehouse and Jonathan A. Lanman ${ }^{47}$ recently updated the former's theory of modes of religiosity, taking into account the contribution of rituals to the development of different kinds of solidarity and social cohesion among members of religious groups and communities.

According to their theoretical insights, rituals of high frequency that induce low emotional arousal are usually performed in communities of large scale that are organized around a central authority. Such communities are classified in the 'doctrinal mode of religiosity' that promotes the storage of specific bodies of creeds and complex conceptual knowledge in the participants' semantic memory through regularly repeated and routinized rituals. The sharing of such semantic knowledge among the members of the community comprises the "prototypical characteristic" ${ }^{48}$ that determines

${ }^{44}$ See Burkert (n. 2) 42-43, 98-99; GORdON, R. L.: Mithraism and Roman Society. Religion 2.2 (1972) 101 .

${ }^{45}$ We do not surely know whether there was an initiatory ritual to each grade or one single ritual of initiation into the mysteries. In any case, long-term participation in the cult could entail the gradual access of the initiates to the Mithraic world view. See GORDON: Mithraism (n. 44) 97; CLAUSS (n. 27) 102105. For a summary of the known Mithraic initiatory rituals see BECK: Ritual (n. 16) 146, n. 10.

${ }^{46}$ For relative references, see WHITEHOUSE-LANMAN (n. 7).

${ }^{47}$ The theory of modes of religiosity suggested by Whitehouse (WHITEHOUSE, H.: Inside the Cult: Religious Innovation and Transmission in Papua New Guinea. Oxford 1995; WHITEHOUSE, H.: Modes of Religiosity: Towards a Cognitive Explanation of the Sociopolitical Dynamics of Religion. MTSR 14 [2002] 293-315; WhitehouSE, H.: Modes of Religiosity: A Cognitive Theory of Religious Transmission. Walnut Creek CA 2004) has received critique by both anthropologists and historians of religion. After publishing his theory in 2004, Whitehouse updated his theoretical considerations. Particularly in their joined article, WhITEHOUSE-LANMAN (n. 7) provide new insights into the connection between the two modes of religiosity and different kinds of social cohesion developed in different sorts of social communities.

${ }^{48}$ Whitehouse-LANMAN (n. 7) 678 referring to TAJfEL, H. - TURNER, J. C.: An Integrative Theory of Intergroup Conflict. In AUSTIN, W. G. - WorCHEL, S. (eds): The Social Psychology of Intergroup Relations. Monterey, CA 1979, 33-47, and TURNER, J. C.: Social Categorization and the SelfConcept: A Social Cognitive Theory of Group Behavior. Adv. Group Process: Theory and Research 2 (1985) 77-122. 
'group identification': the self-identification of someone as a member of the community and the recognition of others as co-participants in the same community. In this kind of social organization, the members of the group are not directly associated with each other - they do not even necessarily know one another - but they are connected through the central node of the authoritative figure(s). Since all the members do not develop personal relationships with each other, the social cohesion of the community is loose and normally does not promote extreme pro-social behaviors and the tendency for self-sacrifice for the benefit of the group. ${ }^{49}$

Communities classified in the 'imagistic mode of religiosity', on the other hand, greatly depend their existence on the performance of highly arousing rituals. Such religious traditions normally lack a specific body of creeds and ideas, the sharing of which would provide the objective criterion for the identification of group members. In that case, participation in the rituals is the common 'prototypical characteristic 50 that is recognizable by participants in order to classify themselves and others in the same group. High emotional arousal during infrequently performed rituals facilitates the storage of the personal experience of participation in individuals' episodic memory. The sharing of such common episodic memories among co-participants is perceived as an essential element of both their life-stories and identities that generates 'identity fusion' and connects the members of the group with relationships of psychological kinship. ${ }^{51}$ Such personal relationships, when based on common emotional experiences shared by people, can develop in small-scale groups. In such a mode of social organization there is no need for a central node - represented by a central authoritative figure - through which the members are connected with each other. On the contrary, each member is a node in the social network of the group that is directly connected with the other members-nodes. In these settings, the personal relationships among the members resemble family bonds and promote pro-social and self-sacrificial behaviors. ${ }^{52}$

Exploring the impact of high emotional arousal to the generation of social cohesion in groups and communities, Whitehouse and Lanman ${ }^{53}$ mainly focused on dysphoric religious rituals without denying the possibility for euphoric arousal to have similar effects. ${ }^{54}$ There is, however, a largely neglected aspect of many religious rituals that contributes to social cohesion and increases emotional arousal during and after the participation in ritual practices. This is the demand for secrecy and concealment ${ }^{55}$

${ }^{49}$ See Whitehouse-LANMAN (n. 7) 676-678.

${ }^{50}$ See above n. 47.

${ }^{51}$ See Whitehouse-LanMan (n. 7) 680-681.

${ }^{52}$ WhiteHOUSE-LANMAN (n. 7) 679.

${ }^{53}$ Whitehouse-LANMAN (n. 7) 675.

${ }^{54}$ See also the comments of Greg Downey, Daniel H. Lende, and Dimitris Xygalatas on WHITEHOUSE- LANMAN (n. 7) 683-684, 685-686, 689-690.

${ }^{55}$ After SiMmeL (n. 9) who studied the sociological role of secrecy, this aspect of religious rituals has received little attention by modern anthropologists as well as by cognitive scientists of religion. Recently, Michael Genkin studied the connection between secrecy and social cohesion; see GENKIN, M.: Simmel in the Laboratory: An Experimental Investigation into the Relationship Between Secrecy and Cohesion. Unpublished MA thesis, Cornell University 2010. 
that characterizes many religious groups, mainly of the imagistic mode of religiosity. As we have underlined, Greco-Roman mystery cults and the cult of Mithras in particular comprise a significant paradigm of rituals of high emotional arousal that took place in secret. ${ }^{56}$

The fact that we do not know what exactly happened during the Mithraic rituals is largely due to the demand for concealment of the initiates' experiences. From a few scattered visual representations ${ }^{57}$ and some references, mainly in Christian sources, ${ }^{58}$ we can assume that the initiates would have experienced high dysphoric arousal during initiation. ${ }^{59}$ The sharing of these dysphoric experiences and of the entailed episodic memories would have generated the feeling that the co-participants shared a crucial part of their lives that fused their self-concepts and social identities, and bonded them with relationships of fictive kinship. ${ }^{60}$ In this social network, the grade hierarchy did not correspond to a kind of core authority but mainly played an internal symbolic role that, as we have seen, determined the access, positions, roles and duties of each member within the cult-community as well as the initiates' personal and social identities. ${ }^{61}$ The Mithraists, however, had to conceal their cult identities as well as their internal roles and duties from the outsiders. Thus, we here find an exemplar of the 'paradox of secrecy' as determined by Bellman. ${ }^{62}$ The Mithraists shared similar emotionally arousing experiences with their co-participants, they inhabited specific roles and executed certain actions that were known to the insiders and they could talk about their personal memories and reflections with other members. At the same time, however, they had to keep any aspect of this significant part of their lives hidden from the outsiders. They were not allowed to talk about any of these things with their natural relatives or friends and acquaintances outside of the ritual context, a prohibition that could generate emotional tension and anxiety. ${ }^{63}$

A series of four experiments conducted by Julie D. Lane and Daniel M. Wegner $^{64}$ explored the cognitive consequences of keeping secrets. The results indicate that as people attempt not to expose a secret they put greater efforts into controlling their minds and suppressing any thinking about the secret. This suppression generates intrusive thoughts and obsessive preoccupation with the secret that leads to further attempts of suppression and so on. This loop may induce feelings of anxiety and fear

\footnotetext{
${ }^{56}$ MARTIN (Performativity [n. 27] 193-194) was the first who suggested the classification of the Mithras cult in the imagistic mode of religiosity.

${ }^{57}$ E.g. the series of frescos on the front side of the benches in the Mithraeum at Capua (V187-97; Vermaseren, M. J.: Mithraica 1: The Mithraeum at Santa Maria Capua Vetere [ÉPRO 16]. Leiden 1971).

${ }^{58}$ E.g. Ambrosiaster, Quaestiones Veteris et Novi Testamenti CXIV 11.

${ }^{59}$ See e.g. GORDON: Reality (n. 16) 24; BURKeRT (n. 2) 102; ClAUSS (n. 27) 102-105; MARTIN: Performativity (n. 27) 191.

${ }^{60}$ Cf. WHiteHOUSE-LANMAN (n. 7) 677.

${ }^{61}$ On the symbolic role of hierarchies in imagistic religious traditions see WHITEHOUSE, H.: Modes of Religiosity. CSSR Bulletin 37.4 (2008) 110-111.

${ }^{62}$ Bellman (n. 8).

${ }^{63}$ See GENKIN (n. 55) 13.

${ }^{64}$ Lane, J. D. - Wegner, D. M.: The Cognitive Consequences of Secrecy. J Pers Soc Psychol 69.3 (1995) 237-253.
} 
of exposure. These unpleasant feelings, along with the undesirable thoughts of the secret, are eliminated when a secret-keeper is among others who also know the secret. The relaxation of the cognitive efforts for concealment, of the preoccupations with exposure and of the emotional tension enhances intra-group social cohesion and the psychological bonds among those who share a secret, while in parallel amplifies the borderlines between group-insiders and outsiders. ${ }^{65}$

These borders are further enhanced by the beliefs in the benefits of secrecy. The sharing of the secret experience of initiation and participation in the Mithras cult was believed to obtain a privileged position for the initiates that the uninitiated lacked. They developed a personal relationship with Mithras, who was the sustainer of the universe, and put themselves in his services, enjoying his protection. Simultaneously, they reached a world view that attributed order and meaning to the cosmos and provided a new orientation in their lives. The maintenance of these privileges would be a personal motive for the participants to preserve the secrecy by remaining loyal to the demands for concealment of the intra-group activities. ${ }^{66}$

Along with the personal motives for retaining concealment, the preservation of a secret community presupposes that the members of the group also trust their coparticipants and believe that the latter would not expose the secret. The individuals, who voluntarily undergo stressful, dysphoric or even painful rituals, intend to signal their loyalty and commitment to the cult community. Thus, such costly rituals provide the means through which members of a group can demonstrate their trustworthiness to their co-participants, increasing intra-group solidarity and social cohesion ${ }^{67}$ In this light, participation in the initiatory rituals of the Mithraic cult not only comprised a significant personal experience that entailed benefits shared by the initiates, but further played a social role for signaling the commitment of the participants to the group that would ensure the sustainment of these benefits for the community of Mithraists.

\section{CONCLUSION}

The Mithras cult seemed to display the major characteristics of the imagistic mode of religiosity, as determined by Whitehouse and Lanman. ${ }^{68}$ As the preserved evidence indicates, there was no specific body of creeds and beliefs that participants learned through lectures and teaching by a central authority during highly routinized rituals of low emotional arousal. On the contrary, Mithraists were initiated into a new view of the cosmos through the lived experience of initiatory rituals that would induce high emotional arousal. Initiation (or even initiations in the sequential grades) would have

\footnotetext{
${ }^{65}$ See SiMMEL (n. 9) 480; GENKIN (n. 55) 6-7.

${ }^{66}$ Cf. GENKIN (n. 55) 28.

${ }^{67}$ On the participation in costly religious rituals as a social signal see e.g. IRONS, W.: Religion as a Hard-To-Fake Sign of Commitment. In NESSE, R. (ed.): The Evolution of Commitment. New York 2001, 292-309; Bulbulia, J.: The Cognitive and Evolutionary Psychology of Religion. Biol. Philos. 19 (2004) $655-686$.

${ }^{68}$ WHITEHOUSE-LANMAN (n. 7).
} 
been a personal experience that would have been conceptualized as a significant episode in the initiates' autobiographical memory, affecting their self-perception and the ways they perceived their co-participants, others, and the world. The organization and diffusion of the cult in small, exclusive communities would favor the development of close personal relationships among members of local cult-cells that would contribute to intra-group cohesion and solidarity.

The classification of the Mithras cult in the imagistic religious traditions seems to throw some light on the connection between its internal organization and symbolic structures, and its spread throughout the Greco-Roman world. This paper, however, has further pointed out secrecy as a significant aspect that would have intensified the means and effects of the Mithraic practices and symbolic systems on the participants' emotional and cognitive states, and would have contributed to the great diffusion and success of the cult among people of Roman antiquity.

In particular, it is suggested that secrecy and concealment comprise a crucial factor that is connected to the inducement of high emotional arousal and could have similar effects with highly dysphoric and euphoric rituals. Further research conducted both by historians and cognitive scientists may provide more insights into the connection between secrecy, rituals and social cohesion as well as into the cognitive mechanisms, emotional effects and social impacts of secrecy that have contributed to the diffusion and popularity of various mystery cults and religious practices throughout human history.

Olympia Panagiotidou

PostDoc Researcher, Aristotle University of Thessaloniki

Fellow Researcher, A.U.TH. Research Committee

Greece

Olympia.pana@gmail.com 
